\title{
Études/Inuit/Studies
}

\section{DICK, Lyle 2001 Muskox Land: Ellesmere Island in the Age of Contact, Calgary, University of Calgary Press, Xxv + 615 p., figures, index, notes, and bibliography.}

\section{Chris Paci}

Volume 26, numéro 1, 2002

Perspectives inuit et qallunaat : points de vue en interaction

Inuit and Qallunaaq perspectives: Interacting points of view

URI : https://id.erudit.org/iderudit/009281ar

DOI : https://doi.org/10.7202/009281ar

Aller au sommaire du numéro

\section{Éditeur(s)}

Association Inuksiutiit Katimajiit Inc.

ISSN

0701-1008 (imprimé)

1708-5268 (numérique)

Découvrir la revue

Citer ce compte rendu

Paci, C. (2002). Compte rendu de [DICK, Lyle 2001 Muskox Land: Ellesmere Island in the Age of Contact, Calgary, University of Calgary Press, $\mathrm{xxv}+615 \mathrm{p}$., figures, index, notes, and bibliography.] Études/Inuit/Studies, 26(1), 203-205.

https://doi.org/10.7202/009281ar d'utilisation que vous pouvez consulter en ligne. 


\section{Recensions / Book reviews}

DICK, Lyle

2001 Muskox Land: Ellesmere Island in the Age of Contact, Calgary, University of Calgary Press, xxv + 615 p., figures, index, notes, and bibliography.

I am in full agreement with Rick Riewe's assertion that the book, Muskox Land, is a significant contribution to Arctic history and anthropology. As environmental history, this book studies the "forces exerted by climate on geography and human history and the complex interrelationships of nature and culture, including the impact of humans on ecosystems and the influence of ecology on human history" (p. 3). Lyle Dick has mustered an impressive body of literature for his subject Umingmak Nuna, the Inuit / Inughuit word for present day Ellesmere Island. The book covers a poorly understood and contested cultural and historical geography (including Greenland). With this new book, a great deal of research is made accessible to novice and expert alike. Furthermore, the book is also a valuable addition to the history of globalization and imperialism. For example, the 1885 quote about "American Manifest Destiny" from General Benjamin Butler of the US army adds to discussions about sovereignty claims to the Arctic (p. 210).

The inclusion of aboriginal voices to the pre-eminent Euro / American / Canadian histories is a welcome reprieve. The book is engaging because Dick has written a wellstructured thematic story of the contact between local and outside forces. The chapters are set in four sections, each with an excellent introductory summary. For those interested in research there are extensive endnotes and a full index. There are editorial problems with the notes, with excessive use of $i b i d$. which do not necessarily reference to first citations (for example, see page 530). Despite this shortcoming, the real strength of this book is the author's commitment to let readers decide what to believe. I applaud the author's presentation of the story, a post-modernism void of pretentious rhetorical dressings. Dick asserts that inclusion or consideration of voice is the basis for presenting different cultural conceptions of time (cosmology). These structural differences are fundamental to understanding and telling history.

For those with knowledge of the North you will be aware of much of the contact history of the Fur Trade, numerous arctic explorers and adventures, the search for a Northwest Passage, Inuit cultures and their art, and government programs to form settlements. Dick notes: "For more than the backdrop to human history, the environment is conceived as a major agent of history that unavoidably influenced the decisions and actions of the people operating within it" (p. 3). Inuit responses and roles in these largely outside views, southern endeavours, have, until recently, been ignored and mis-understood. Ellesmere Island into the Age of Contact has filled a gap presenting, "an alternative [way] of conceptualizing or presenting the past" (p. 481). In other words, telling the epic adventure tales grounded in academic research without 
losing the adventure and retreat of such journeys. Dick takes us beyond the tales of tragedy, to a point where the narrative history of Inuit-Euro contact becomes much easier to understand, in part because more voices have been gathered to testify on what transpired. Dick's goal is to create "a balanced and comprehensive account. The presentation of a wide-ranging selection of stories from Ellesmere Island's past [to maybe] also assist readers in developing their own interpretations about the region's history to counter balance the monolithic verities in exploration literature" (p. 482). Like a member of the jury the reader is left to decide.

Rather than argue the significantly different ways that history has been constructed, Dick asks readers to consider all the evidence (different and sometimes competing histories), an approach that is rooted in his background as a Parks Canada historian. In his role as a "public" historian, he would have had ample opportunity to work with diverse audiences. Dick's work on the history of Quttinirpaaq National Park (Ellesmere Island National Park Reserve) is meant to provide a better view to understand and represent arctic history. Not to condemn all other historians, but too often academics tend to be married to teaching and popular historians tend to overdo the feats and tragedies, each for a particular audience.

The story of Ellesmere Island is a rich history of relationships; diverse environments, cultures and circumstances that, combined, have created history. Dick identifies the point of change as an intersection of "the short term of events, the longterm of natural environment and culture, and the medium term of social change, that individual and collective destinies have been shaped" (p. 482). The research methodology employed for the book was "to assemble data from a wide range of unpublished archival documents and oral history sources" (p. xvii). The theoretical approach taken by Dick is based on Fernand Braudel's "structural, multi-dimensional approach to temporality" as a model "for addressing the complexities of historical continuity and change" (p. xxii).

There are editorial problems with this book and the people at University of Calgary Press need to be much more thorough in the future. There are numerous typos and spelling errors, for example: on page 14 "Grand Land Ice Cap" should be Grant; on page 51 "not a wide range of a sophisticated tools" and there are numerous (too many to cite here) instances where quotation marks are missing (for an example, see the Stephenson quote on page 175).

There is a significant environmental message in the story of Ellesmere Island that is timely. Dick notes "the eventual synthesis of Aboriginal environmental knowledge and European technology enabled effective exploration but placed heavy stress on the Island's wildlife resources, particularly muskoxen. Throughout the period [1500present], the climate continued to exert an irresistible force. Accommodated but never overcome, it continued to play a major role in all acts of the unfolding drama" (p. 30). Students of traditional knowledge will be happy to read about the dynamic nature of cultural traditions, for example, "Inughuit survival through dramatic changes in the arctic environment cannot be explained solely by reference to their accumulated knowledge $[\ldots]$ they needed to be able to improvise according to unexpected 
circumstances [...] Inughuit displayed a capacity to adapt and solve problems for which there were no pre-existing models or templates" (p. 97). There is, however, no reason to find Dick's conclusions ground-breaking, and there is no way to know in fact if there were no "pre-existing models or templates." With this said, there is enough evidence in this book to give Lyle Dick the credit of the doubt, in the rare instances that he stretches his conclusions beyond the evidence he is able to gather.

Overall, the chapters are complimented by a rich display of maps and archival photos. The illustrations are effectively tied to text and enhance the story a great deal. Muskox Land: Ellesmere Island in the Age of Contact is a valuable book that I have gladly added to my library.

Chris Paci

Yellowknife, Canada

\section{DUHAIME Gérard (dir.)}

2001 Le Nord. Habitants et mutations, Sainte-Foy, Les Presses de l'Université Laval et Le Groupe d'études inuit et circumpolaires, xii et 227 pages (collection Atlas historique du Québec, dirigée par Serge Courville et Normand Séguin).

Dans cet ouvrage, Gérard Duhaime et ses collaborateurs proposent une introduction à la géographie humaine, l'histoire, la démographie et l'ethnographie des populations autochtones et non autochtones du Nord québécois (défini ici comme comprenant la Côte-Nord du Saint-Laurent, le territoire de la baie James, les terres des Naskapis, ainsi que le Nunavik). Le volume se divise en deux grandes sections, l'une plus historique et ethnographique («Les habitants du Nord»), l'autre traitant des changements socio-économiques depuis l'arrivée des Européens («Les mutations du Nord»). La première section se subdivise en six chapitres, portant chacun (sauf le premier, qui traite de la préhistoire de la région) sur une population particulière: NordCôtiers non autochtones, Innus-Montagnais, Cris de la baie James, Naskapis, et Inuit. La deuxième section décrit quatre aspects importants du changement socio-économique dans le Nord québécois: l'exploration (et la cartographie), la traite des fourrures, l'industrialisation, et la sédentarisation des autochtones. Une introduction et une courte conclusion de Gérard Duhaime tentent de lancer le débat sur le sens de l'histoire nordique québécoise qui, selon l'auteur, se caractérise par une réduction et une bureaucratisation progressives des populations autochtones.

L'ouvrage est généralement bien écrit, complet et intéressant. La liste des auteurs regroupe tous les grands spécialistes locaux des populations du Nord du Québec: Gérard Duhaime, bien sûr, mais aussi Benoît Robitaille, Paul Charest, Bernard Saladin d'Anglure, François Trudel, Carole Lévesque, Yves Labrèche et Nick Bernard. Seuls trois noms manquent à l'appel: Louis-Edmond Hamelin (à qui le livre est cependant dédié), Marc-Adélard Tremblay et Jean-Jacques Simard. Aucun Autochtone (à l'exception de Charleen Rains, co-auteure du chapitre sur les Naskapis) n'a participé à l'ouvrage, ce qu'on peut déplorer puisque — et c'est là un des attraits du volume - huit 